\title{
MICRO-FINANCE FOR POOR AND NON-POOR COMMUNITIES OF NEPAL
}

\author{
Chandra Prasad Dhakal*
}

\begin{abstract}
The micro-finance institutions are providing service to the people with the noble purpose to improve their socio-economic status which ultimately helps to reduce the poverty Nepal. In the Nepalese context, micro-finance institutions are providing the equal services to all people living in the remote and rural areas. The main objective of this study was to identify the economic importance of micro-finance institutions for poor and non-poor communities of Nepal. The study was conducted in Syangja district among the 385 beneficiaries of micro-finance. This study found that there was no significant association between the poor and non-poor people regarding the success of small scale business with the support of micro-finance, and increasing the amount of saving because $p$ $=.524$ and .402 respectively which was greater than .05 significant levels. The difference could be observed in the increase in income level of poor and non-poor. Slight better improvement could be seen among the poor people, there was significant association between poor and non-poor because of $p=.019$.
\end{abstract}

Keywords: Economic, importance, micro-finance, Nepal, poor

\section{INTRODUCTION AND OBJECTIVE}

Agriculture is the backbone of developing countries of the world and this segment has an enormous potential to support the agricultural growth and economic advance and can reduce poverty (Zeller, 2003). Nepal is an agricultural country because of 1362908.2 hector of land being suitable for paddy production, 745823.164 hector land is suitable for wheat production, 891583 hector land is suitable for maize, 266799 hector land is suitable for millet, 28361 hector land is suitable for Barley (CBS, 2016). In this context, development activities focusing on the poverty reduction were started in 1994 under the auspices of the South Asia Poverty Alleviation Program (SAPAP) of the UNDP, received millions of dollars of international investment and has become a model for national development. Syangja's model was proved to be successful that the Government of Nepal joined

* Mr. Dhakal is a Lecturer, Saraswoti Multiple Campus, Lekhnath Marg, TU. 
forces with the SAPAP to extend the project to other districts and make it a model for national development. Micro-finance activities were also initiated before two decades with the objective of poverty reduction. Very poor, disadvantage, marginalized and women were the main target group of micro-finance activities. The main objective of almost all microfinance institutions is to deliver financial services to the poor. Microfinance refers to the delivery of financial services such as credits, savings, insurance and other facilities to shoppers who are without access to the services of formal sector, financial institutions on sustainable basis (Hashemi, Schuler, Sidney, \& Riley, 1996). Microfinance became one of the important tools of reaching the poor who had very limited access to the formal financial sector. Very limited researches concerning improving the financial sector have been observed (Wolday, 2005).

Financial services to poor people, particularly from rural areas may help farmers to access new technologies and high yield varieties for agriculture production. Provision of financial services and products has trickle-down effects on the poor's livelihood. Microfinance for agriculture has the potential to address all factors, which are linked to poverty reduction, e.g. improved health, better education, better agricultural practices and employment opportunities (Komives, Halpern, Foster, \& Wodon, 2005). Poverty alleviation is very massive and broad issue that encompasses government policies, education, health care, rural substructure, employment prospects, provision of credit and financial services. Poverty reduction is a main planning instrument in improvement and there are number of poverty reduction strategies. It is not possible to address all strategies separately in this limited study. However, this study identifies microfinance for rural agriculture as an important strategy for poverty reduction in the rural agricultural sector. Because in this technologically advanced era the farmers must have knowledge of crop variety, weather, fertilizer etc. to maximize production and profits. Rural infrastructure is necessary to carriage the products to main agricultural markets. Provision of credit and financial services is one of the key approaches of poverty reduction that increases the confidence of poor to take initiative to start new microenterprises in developing countries. Therefore, the features of the policy have strong potential to alleviate poverty from any poor country.

Micro-finance is one media to support the community to improve their economic status. Microfinance programs and institutions have become an increasingly important component of strategies to reduce poverty or 
uphold micro and small enterprise development. However, knowledge about the achievements of such initiatives remains only partial and contested. At one extreme are studies arguing that microfinance has very beneficial economic and social impacts (Hossain, 1988). In the context of Nepalese economics, it has been found used in Nepal only in the later part of 1990s. Although rustic credit in Nepal began in 1956 with the opening of Credit cooperatives in Chitwan Valley to provide loans to the re-settlers coming from different parts of the country (Shrestha, 2009, p. 11). Since then, Micro-finance institutions are providing the service to the rural society. So, it is equally important for the all regional people; either poor or rich because it has been providing the saving, credit service to all. The main objective of this study is to identify the economic importance of micro-finance to poor and non-poor people of Nepal; basically in the case of Syangja district.

\section{METHODOLOGY AND STUDY AREA}

This study is based on the descriptive and exploratory design. The data was collected from the Syangja district among the 385 beneficiaries of Micro-finance. Syangja District, a part of Province No. 4 out of 7 Province, is one of the seventy-seven districts of Nepal as the new administrative division under

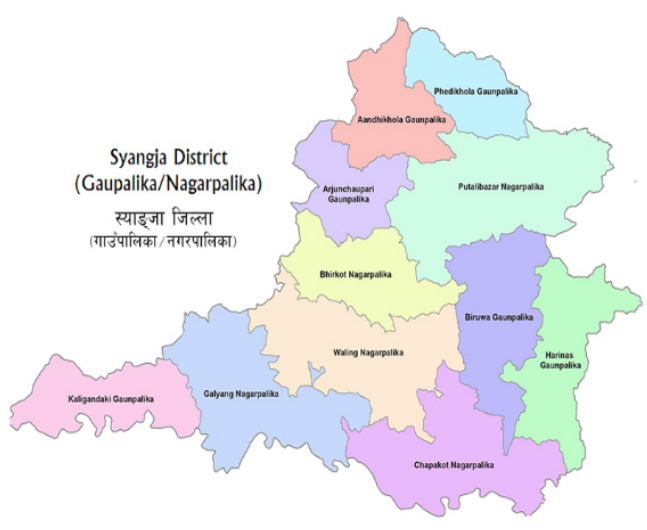
the Constitution of Nepal 2072 BS. It was a cross-section study. It is pure quantitative study; data was collected by using the structured questionnaire survey. The sample size was calculated by using the sample calculation formula; 95 percent confidence levels, 5 percent margin of error. The simple random sampling technique was used to select the name of beneficiaries. The study had collected the list of beneficiaries from the Micro-finance offices and did the lottery method to select the respondent. The study took only one respondent from one household. It was done household survey. The researcher visited the individual house and took the pre-consent from respondent for data collection. The instruments were pre-tested to ensure the quality of data. The collected data was analyzed from the SPSS and presented in the tabular form. The study had divided the total respondent in between poor and non- 
poor by following the poverty likelihood legacy definition lines following the National Poverty Line. The cross-tabulation, mean and Chi-Square test were run to analyze the data. Statistical difference was observed between the poor and non-poor.

\section{ANALYSIS}

The respondents were asked about role of microfinance to promote small scale businesses. The following table shows the results.

Table 1: Small Scale Businesses Based on Microfinance

\begin{tabular}{|c|c|c|c|c|c|c|c|c|c|}
\hline & \multicolumn{5}{|c|}{$\begin{array}{c}\text { Responses Analysis About Small } \\
\text { Scale Business Based on Microfinance }\end{array}$} & \multirow[b]{2}{*}{ Total } & \multirow[b]{2}{*}{ Mean } \\
\hline & & & 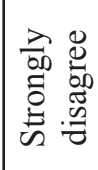 & $\begin{array}{l}\mathscr{d} \\
\stackrel{d}{5} \\
\mathbb{E} \\
\stackrel{0}{0}\end{array}$ & $\begin{array}{l}\frac{T}{0} \\
\frac{0}{0} \\
\frac{0}{0} \\
\tilde{D}\end{array}$ & 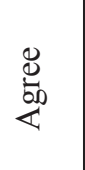 & 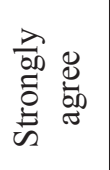 & & \\
\hline \multirow{4}{*}{$\begin{array}{l}\text { National } \\
\text { standard } \\
\text { of } \\
\text { poverty }\end{array}$} & \multirow{2}{*}{ Poor } & Count & 4 & 12 & 51 & 55 & 18 & 140 & \multirow{2}{*}{3.50} \\
\hline & & $\%$ & 2.9 & 8.6 & 36.4 & 39.3 & 12.9 & 100.0 & \\
\hline & \multirow{2}{*}{$\begin{array}{l}\text { Non } \\
\text { poor }\end{array}$} & Count & 14 & 15 & 100 & 86 & 30 & 245 & \multirow{2}{*}{3.4204} \\
\hline & & $\%$ & 5.7 & 6.1 & 40.8 & 35.1 & 12.2 & 100.0 & \\
\hline \multirow{2}{*}{\multicolumn{2}{|c|}{ Total }} & Count & 18 & 27 & 151 & 141 & 48 & 385 & \multirow{2}{*}{3.4519} \\
\hline & & $\%$ & 4.7 & 7.0 & 39.2 & 36.6 & 12.5 & 100.0 & \\
\hline \multicolumn{10}{|c|}{ Chi-Square Tests } \\
\hline & & & & Value & $\mathrm{df}$ & \multicolumn{4}{|c|}{ Asymp. Sig. (2-sided) } \\
\hline \multicolumn{4}{|c|}{ Pearson Chi-Square } & 3.207 & 4 & \multicolumn{4}{|r|}{.524} \\
\hline
\end{tabular}

Source: Field survey, 2016

The results show that out of 385 respondents, $18(4.7 \%)$ strongly disagreed, 27(7\%) disagreed, 151(39.2\%) were undecided, 141(36.6\%) agreed and 48(12.5\%) strongly agreed on success of small-scale businesses where microfinance banks invested with mean value of total is 3.4519. In comparison of poor and non-poor, the mean value of poor is 3.5071 whereas mean value of non-poor is 3.4204. The statistical analysis of Chi-Square test shows that there is no significant association between poor and nonpoor regarding the success of small-scale businesses where microfinance banks invested because the $\mathrm{P}=.524$ which is greater than .05 significant level (Table 1). 
The result is not as satisfactory as objective of microfinance institutions because those institutions' main goal is to uplift small-scale investors. Further, they need to correct it.

Opinions of respondents about their increment of income after joining microfinance banks were taken. The following table shows the results of it.

Table 2: Income Status After Joining Microfinance

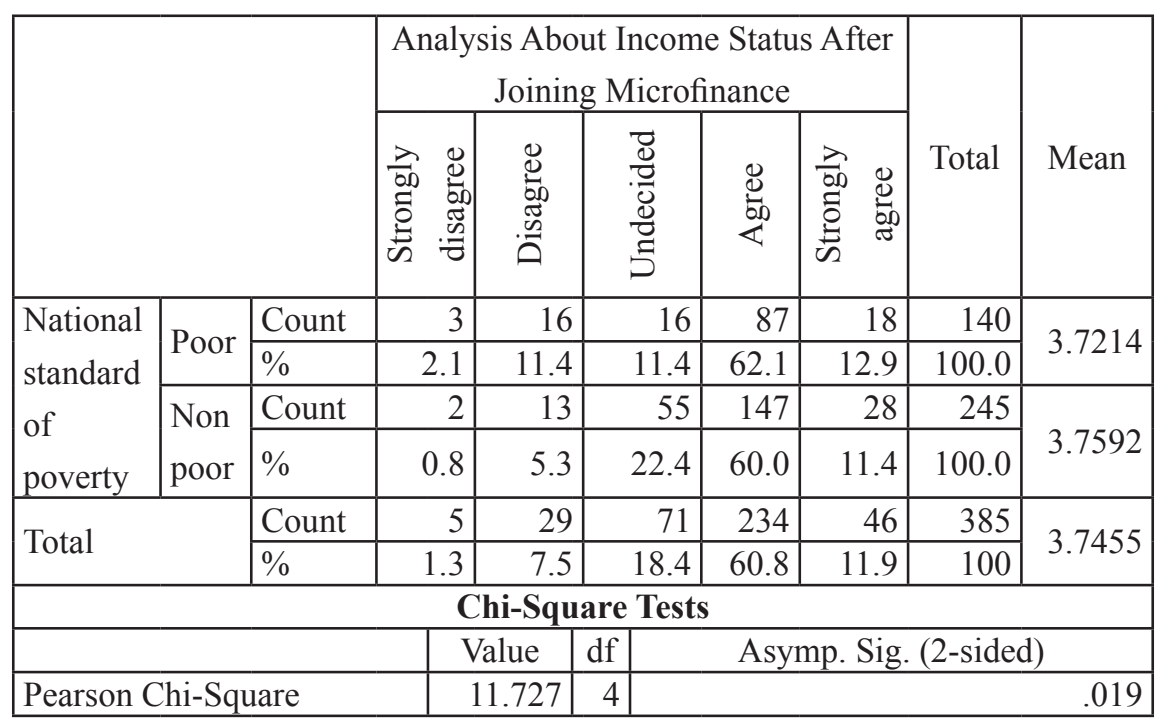

Source: Field survey, 2016

Income determines the economic status of people. Out of 385 respondents, 5(1.3\%) strongly disagreed, 29(7.5\%) disagreed, 71(18.4\%) were undecided, 234(60.8\%) agreed and 46(11.9\%) strongly agreed with mean value of total is 3.7455 . In comparison of poor and non-poor, the mean value of poor is 3.7214 whereas mean value of non-poor is 3.7592 . The statistical analysis of Chi-Square test shows that there is significant relationship between poor and non-poor regarding the incensement in income with support of microfinance banks because the $\mathrm{P}=.019$ which is less than .05 significant level. The result shows that microfinance banks are helping in poverty reduction (Table 2).

The respondents were asked whether their savings have been increased after joining microfinance programs or not. The results of it are shown in the following table. 
Table 3: Status of Saving After Joining Microfinance

\begin{tabular}{|c|c|c|c|c|c|c|c|c|c|}
\hline & \multicolumn{5}{|c|}{$\begin{array}{l}\text { Analysis About Status of Saving } \\
\text { After Joining Microfinance }\end{array}$} & \multirow[b]{2}{*}{ Total } & \multirow[b]{2}{*}{ Mean } \\
\hline & & & 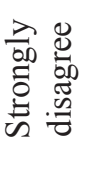 & 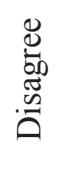 & 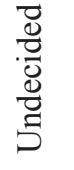 & 递 & 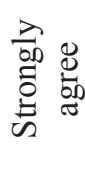 & & \\
\hline \multirow{4}{*}{$\begin{array}{l}\text { National } \\
\text { standard } \\
\text { of } \\
\text { poverty }\end{array}$} & \multirow{2}{*}{ Poor } & Count & 3 & 10 & 23 & 92 & 12 & 140 & \multirow{2}{*}{3.714} \\
\hline & & $\%$ & 2.1 & 7.1 & 16.4 & 65.7 & 8.6 & 100.0 & \\
\hline & \multirow{2}{*}{$\begin{array}{l}\text { Non } \\
\text { poor }\end{array}$} & Count & 2 & 9 & 46 & 162 & 26 & 245 & \multirow{2}{*}{3.8204} \\
\hline & & $\%$ & 0.8 & 3.7 & 18.8 & 66.1 & 10.6 & 100.0 & \\
\hline \multirow{2}{*}{\multicolumn{2}{|c|}{ Total }} & Count & 5 & 19 & 69 & 254 & 38 & 385 & \multirow{2}{*}{3.7818} \\
\hline & & $\%$ & 1.3 & 4.9 & 17.9 & 66.0 & 9.9 & 100.0 & \\
\hline \multicolumn{10}{|c|}{ Chi-Square Tests } \\
\hline & & & \multicolumn{2}{|c|}{ Value } & \multicolumn{2}{|c|}{ Df } & \multicolumn{3}{|c|}{ Asymp. Sig. (2-sided) } \\
\hline \multicolumn{3}{|c|}{ Pearson Chi-Square } & \multicolumn{2}{|c|}{4.032} & \multicolumn{2}{|r|}{4} & \multicolumn{3}{|r|}{.402} \\
\hline
\end{tabular}

Source: Field survey, 2016

Out of 385 respondents from study areas, 5(1.3\%) strongly disagreed, 19(4.9\%) agreed, 69(17.9\%) were undecided, 254(66\%) agreed and $38(9.9 \%)$ strongly agreed in increment of savings after joining microfinance programs. The result indicates the positive agreement of respondents that they experienced the changes in their economic status and improved the saving with mean value 3.7818 in response of this question. In comparison of poor and non-poor, the mean value of poor is 3.7143 whereas mean value of non-poor is 3.8204. The statistical analysis of Chi-Square test shows that there is no significant relationship between poor and nonpoor regarding the increment in saving with support of microfinance banks because the $\mathrm{P}=.402$ which is greater than .05 significant level (Table 3 ).

The finding is supported by the previous study also. The studies carried out by (Pollinger \& Cordero, 2007) and Hennessey (Hind, 1997) confirmed that microfinance in its various models do assist the world to reduce and alleviate poverty and enhance economic development, particularly in developing economies. Micro entrepreneurs have difficulty in accessing capital from mainstream financial institutions for various reasons ranging from non-availability of appropriate and adequate collateral and inability of the entrepreneurs to provide acceptable accounting records of their businesses. Microfinance in many instances has bridged this gap 
as microfinance institutions have financed many small and medium size businesses.

\section{CONCLUSION}

The study had focused to identify the importance of micro-finance institution from the economic perspective to the poor and non-poor people. The study had adopted poverty likelihood legacy definition lines following the National Poverty Line to divide the total respondent in between poor and non-poor group. There was 140 (36.4\%) were found poor and 245 $(63.3 \%)$ were non-poor on the national level standard of poverty. The core objective of micro-finance institutions are to support the poor people to reduce the poverty though in Nepalese context, such institutions are providing the service to all types of people basically living in the rural and remote areas. In case of Syangja district, almost equal number of poor and non-poor people were benefited from the micro-finance service to promote the small scale business and improving in saving. There was no significant association between the poor and non-poor community in these situation. But there was slight difference was observed in the improvement of income in poor and non-poor people. Slight better change was observed among the poor people than non-poor people.

\section{REFERENCES}

Central Bureau of Statistics. (2016). Statistical pocket book Nepal, Kathmandu: Author.

Hashemi, S., Schuler, R., Sidney, S., \& Riley, P. (1996). Rural Credit Program and Women's Empowerment in Bangladesh. World Development, 24, pp. 635-653.

Hind, A. (1997). The changing values of the co-operative and its business focus. American Journal of Agricultural Economics , 79 (4), pp.1077-1082.

Holcombe, S. (1995). Managing to empower: The Grameen Bank's experience of poverty alleviation. London: Zed Press.

Hossain, M. (1988). Credit for alleviation of rural poverty: The Grameen Bank in Bangladesh. Washington DC: IFPRI.

Komives, K., Halpern, J., Foster, V., \& Wodon, Q. (2005). Water, electricity and the poor: Who benefits from utility subsidies. Washington: World Bank. 
Otero, M., \& Rhyne, E. (1994). The new world of microenterprise finance. London: IT Publications.

Pollinger, O., \& Cordero, G. (2007). The question of sustainability for microfinance institutions. Journal of Small Business Management, 45 (1), pp. 23-41.

Shrestha, S. M. (2009). State of microfinance in Nepal. Kathmandu: Institute of Microfinance.

Wolday, A. (2005). Prudential regulation of the microfinance institutions . Ethiopia: Association of Ethiopian Microfinance Institutions.

Zeller, M. (2003). Models of rural finance of rural financial institutions, Baltimore, USA: World Council of Credit.. 